\title{
Grow More Food Drive and Secondary Curriculum Developments in Colonial Punjab during Second World War \\ * Sumaira Noreen (Corresponding Author)
}

\begin{abstract}
This article presents the case of the British colonial rule and Second World War affecting secondary school curriculum developments in colonial Punjab. The focus rests on the description of those curricular and co-curricular activities that were directed towards war-centric demands for the Grow More Food Drive of Second World War. While aligning secondary education with the emerging needs of the War, the colonial rulers also maintained the confidence of the local educational administration. With the War approaching towards the end, the Indian leaders made their demands upon the British Government to adopt a broader policy emphasizing agricultural knowledge with more of a scientific orientation.
\end{abstract}

Keywords: Second World War, Secondary Education Policy, Secondary Curriculum, Colonial Punjab, Grow More Food

\section{Introduction}

Second World War was a significant time frame affecting every walk of life. When put in the educational context of analysis, Second World War could be seen as a manifestation of, what Webster would call, 'external events' causing 'a crisis of values and ideas' (1976, p.206) and hence 'disrupting the normal' ongoing activities of states (Lowe, 2012, p.4). In other words, the Second World War had implied multiple challenges facing the British Government at the home front and in the context of Indian colonial Punjab. Delimiting the focus of this research only to the education context of colonial Punjab, the British Government had moved towards adopting war centric curricular and co-curricular activities in schools. Schools had become the focal platforms not only catering to the regular scheme of education and promoting positive imagining of war but serving as training centers for providing war services. Schools were also involved but not limited to various war-centric activities including Civic Guards, First Aid, ambulance works, Air Raid Precautions (A.R.P.), gifts contributions not only from the student funds and income from their performances, but also in the form of individual contributions that were made by teachers and students from time to time (Government of Punjab, 1943, pp. 2-10). While all such activities had held great significance for the sake of managing emergencies during War years, the World War had also implied a heightened necessity of growing more food. Siding with the British Government's policy, in Punjab the local educational administrators of secondary education, teachers, and students worked with tremendous zeal towards implementing such significant war-centric demand.

\section{Objective/s and Research Questions}

The focus of this article rests on an objective to explain the measures that were taken by the Punjab Education Department into compliance with British policy for schools during Second World War. The study is delimited to identify and explain the efforts of schools while participating in the British Government's calls for growing more food during war years. The article is based on the following research questions:

1. Why the province of Punjab was so important for the British Government in India to look after the issue of food crises during Second World War?

2. In what ways had the Punjab Education Department corroborated with the Second World War's Grow More Food Drive?

3. What were the achievements and/or implications of such active involvement of Punjab in the British Government's emphasis on increasing food production and sufficiency during the Second World War?

4. How these policies transpired to cater to the post-World War scenario? 


\section{Methodology}

Based mainly on the public record files of the Punjab Education Department for the decades of 1920s to 1940s, this paper presents an empirical study of the case of the British Government's decision to involve Punjab schools in dealing with the food shortage during the Second World War. The sources of primary data collection include Punjab Archives, Lahore, Punjab, Pakistan, and British National Archives at Kew Gardens, UK. The analytic strategy is mainly descriptive and persuasive where reference to the secondary literature is being made to support the main argument of the study.

\section{Agricultural education in schools of Punjab before the onset of Second World War}

There is no denying the fact that for the British Government in the Indian subcontinent Punjab had always remained significant as an agricultural land. So was true about enhancing agricultural education in that fertile land of five rivers. Analysts like Mohan argue that since the beginning of their rule over India, the British were sure that 'botanical-cum-agricultural wealth was to be utilized for industrial and experimentation purposes' (2018, p. 205). The Province of Punjab also held great significance for the British Government in India, because of its active participation in sustaining the fiscal budget of the state but also for 'the sterling contribution of its peasants-turned-soldiers in the imperialist wars in Europe' (Mohan, 2018, p. 208). Hence, closer to the heart of the British Government in India had remained establishing educational institutions or providing assistance to already existing institutions that promised agricultural education in Punjab. From the mid- $19^{\text {th }}$ century to the mid- $20^{\text {th }}$ century, the British Government had adopted various measures to achieve its aims for agricultural education in India. Various examples from history can be cited, including, Education Despatch of 1854 suggesting teaching of agricultural knowledge of practical utility in schools; the Imperial Education Conference of 1923 suggesting to adopt such a general scheme of secondary education which could be combined with the vocational knowledge mainly emphasizing on agricultural education in the rural agricultural areas of India (Tomlinson, 1924, p. 1); Abbott-Wood report of 1937 acclaiming to establish high schools specified in technical, commercial, and agricultural knowledge forms (Kochhar, 2005, p. 117); are but a few to cite here.

By the turn of the $20^{\text {th }}$ century, the government of Punjab had already achieved its targets of adopting agricultural education as an integral part of mainstream school curricula; while some institutions of higher learning and research in agriculture had been established as well. The majority of students attending secondary schools of Punjab had offered subjects of 'practical utility', which included, for instance, agriculture, shorthand, book-keeping, type-writing, and science, etc. (Government of Punjab, 1921, p. 18). According to the Directorate of Public Instruction's report published in 1925, it was with the help of government grants that agricultural centers were being maintained in at least 5 high schools. In those schools, side by side with the teaching of theory subjects some practical training was also offered by expert teachers in the farms that were attached to schools (Government of Punjab, 1925, p. 42). The following two years demonstrated additional improvement in agricultural education hence adding to an increase in the number of agronomists towards the end of the 1920s (Government of Punjab, 1929, p. 51). Certainly, the determination of the educational administrators for adopting secondary school curricula of practical utility in rural-urban Punjab needs a special mention here. The judicious work of curriculum had implied an emphasis on promoting handicraft training for the town schools and the farm work and gardening for schools in rural Punjab (Government of Punjab, 1929, pp. 55-56). Besides, certain incentives were also provided for agricultural and general education in Punjab's schools in the form of free and half-rate fee concessions to students studying in secondary schools (Government of Punjab, 1929, p. 62).

In 1927, the Punjab Education Department had also extended their help to the Education Department of Bengal for adopting practical agriculture in schools. Bengal's Education Department in their Quinquennial report for 1927-1932 explained their adoption of agricultural education in schools on the lines of agricultural education in Punjab after certain re-adjustments were made in Punjab's textbook for its adaption in Bengal's schools (pp. 40-41). At the provincial home front, the Punjab Education Department had successfully engaged students in co-curricular and extra-curricular agricultural activities. Satisfaction was being reported over introducing, what they believed, and 'healthier' influences at work secondary schools when an increased passion of students was being experienced towards involvement in activities like maintaining the school gardens and farms associated with agricultural training (Government of Punjab, 1930, p. 4). 
As the period of 1930s was of financial stringency everywhere; and for Punjab's Education Department one of the solutions lie in 'ruralizing education' (Government of Punjab, 1937, p. 18). The policy had borne fruitful results, not only for students' personal development but also for the uplift of their respective areas. For instance, the Government of Punjab in their Directorate of Public Instruction report for the year 1935-1936, that was published in 1937, stated with jubilation that the sums set in arithmetic were combined with the 'knowledge of practical arithmetic used in the everyday life of zamindars (farmers), local imports and exports, village industries', etc. (p. 18). The report further highlighted that the effects of oral and written compositions which were derived from rural environments and handicrafts practiced in some schools had also developed among students a positive attitude towards 'dignity of labor and rural occupation' (1937, p. 18). Hence, the secondary curriculum with agriculture content had brought quite fruitful results for the people of Punjab and the colonial masters. Saying this, the scope of agro-biased schooling in formal and informal terms was bound to change in the next years to follow. At the home front, the British Government was making pre-World War arrangements to enable people to cope with the pressures of War. In colonial India, the British Government could see more coming from the people of Punjab, especially when they had already supported the British Government during the First World War and the following decades.

\section{Second World War calls for Growing More Food}

It is believed that one-fifth of the entire World's population was at War because Britain was at War; which implied directing colonial resources towards the defense of the global empire (Jackson, 2011, p. 65). The dynamics of War have also been analyzed regarding its effects on food production and distribution during and after the end of War itself (Collingham, 2012). In the colonial context, it is further argued that the War had also meant for colonies an intense focus on agriculture that could be used by the colonial master not only for the sake of coping with insufficient food at home front but could also serve for the capitalist export ventures in the global market (Jackson, 2006, p. 49). For colonial India, such emphasis was not new due to their agro-specific education curricula and research that was being given an impetus since First World War I and onwards.

The British Government in India had been making efforts to affiliate the vocational elements of school education with industrial needs through their policy initiatives such as the Educational Policy Resolution of 1913, and the report of Calcutta University Commission that was published in 1919 (Nayar, 1989, p. 340). Moving on, the Abbott Wood report, which was submitted by mid-1937, had further strengthened such claims for aligning school education with commercial and industrial demands of Indian society (Biswas and Agarwal, 1944). The two-part report could be seen as one of the landmarks in British education policy signifying the dire need for making technical education compatible with the industrial as well as agricultural needs of the Indian people (Krishnaswami \& Krishnaswami, 2006, p. 93). In compliance with the recommendations of the Abbott-Wood report, the then representative government of All Indian National Congress presented their Wardha Scheme of education which was seen as a vivid expression of correlating vocational and technical education with that of mainstream general education. It may be asserted here that being adopted in response to the exploitative nature of the so-called progressive movement of industrialization, the scheme was implemented in some parts of India with a belief that it would serve an agriculturally poor and industrial background country like India. The scheme was also interpreted as to have had upheld the cause of creating a self-reliant rural Indian economy with the help of practically useful vocational education. While the proposed scheme was being approved for implementation, the resignation of Congress ministries during the Second World War jeopardized its effective implementation in a broader spectrum of areas.

The growing tensions of food shortage during the Second World War had added fuel to the fire. It was felt that since the development of agricultural education and technical training in secondary schools were limited to the rural areas, there was a dire need to combine these with the scientific and industrial development in broader terms. Such concerns had held relevance in the $52^{\text {nd }}$ Session of the All India Muslim Educational Conference when Kamal Yar Jung Education Committee was appointed as a part of the Conference deliberations held in December 1939 to look after the issue. The committee consisted of both Indian and British members; including, eminent educated Muslims who had received their degrees from prestigious universities of the UK, and British officers representing the Indian Educational Service. The Kamal Yar Jung Education Committee Report proposed establishing three types of secondary schools in each province, including Secondary Schools 
for Arts and Science, Secondary Schools for Commerce, and Secondary Schools for Agriculture (1942, p.256). Hence the felt need for separate secondary schools for Agriculture was being voiced with unanimity. Such vows for agro-based schooling received an enhanced stimulus with the onset of the Second World War as the War had required food sufficiency side by side with other pressing needs of the hour.

As the Second World War called for its 'Grow More Food' drive, the Punjab education department had responded well to such demands by adopting measures for agricultural education in schools. The initiation of the 'Grow More Food' drive in 1942 further enhanced the production of agricultural farms and plots which had contributed towards an increased food production and fodder crops. This had raised the value of food or fodder crops to Rs. 51,051 in 1942-1943 which initially amounted to Rs. 38,334 in the year 1941-1942; that collectively amounted to Rs. 89,386 for the years 1941 to 1943 (Government of Punjab, 1944, p. 16). Sharing a long history of active involvement in agricultural education, the Government of Punjab felt confident in advising the school teachers of lower secondary schools to use modern ways of producing improved seeds for the sake of better yields of cultivated crops (Government of Punjab, 1944, p. 17). Certainly, the 'Grow More Food' drive during War times had improved the pace of turning Indian agricultural lands into greener provinces. In this context, Punjab needs a special mention where an increase in the total cropped area was being reported to have reached approximately 35 million acres in 1942-3 from its 30 million acres of cropped areas in 1939-40 (Talbot, 1984, p. 600). The Punjabi farmers were not only able to get higher prices for their harvest, they were also able to grow and sell more. Moreover, the rural areas were not only contributing to the agriculture-specific demands of War, but vocational knowledge with an agricultural orientation had also thrived through various knowledge manifestations of rural interest, such as agricultural and industrial handicrafts, farming, floriculture, and gardening. Such depiction of agricultural knowledge with vocational utility in rural areas had not only befitted the Second World War's focus on growing more food, but that also ensured students' acquaintance with the modern agricultural trends in achieving better crop yields of food and fodder.

Similarly, while scores of secondary schools had been closed down due to war pressures in Punjab districts, the student enrolment in yet open schools had gone up during war times. That could be seen as truer for secondary schools in rural areas of Punjab; and the reason for their popularity could be attributed to the schools' ability and zeal for providing training in rural economy specific areas including farming, gardening, floriculture, agricultural and industrial handicrafts, and other ancillary activities (Government of Punjab, 1943, p. 3). Consequent upon improvements in receiving financial support for agricultural farms, the Government of Punjab expressed their jubilation over their achievements in the training quality and outputs. By 1943, on one side, the farms were being turned into open-air laboratories for instruction and demonstration of agricultural education, on the other side, their yields had brought in profits as being manifested by agro-subsidiary industries such as fruit growing, taat (sackcloth) weaving, soap making, rope twisting, basket making, and sericulture, etc. (Government of Punjab, 1944, p. 10).

During peak years of War, while the agricultural education had served the interest of the ruler and the ruled, the emergent lags within scientific knowledge and technical education had not been looked after well. With the Second World War approaching towards the end, such realizations had held a stronghold in the minds of Indian people who could not see them yet fitted in the exalted positions of scientific knowledge, state administration, and industrial development. Similarly, in the progressing years of war, the British Government had sensed their victory. And, for the British Government in India, the time was ripe for planning a shift in the focus towards post-World War adjustments. Equally important was the British Government's sensitizing to the continuing demands of Indians for scientific and technical education that had vowed for government's attention.

Of all the educational development, the development of scientific and technical education had formed the core of Indian demands from the government. The insistence for an increased technical education conducive for industrial development had worked as a permanent demand of the Indian nationalist movements that had voiced their concerns from the platforms of the Indian National Congress, the Muslim League, and other progressive groups. Reminding back the British Government of their calls for the scientific development of knowledge in the first year of the onset of the Second World War, the All India Muslim Educational Conference took up the task again in December 1945, the year when the Second World War had ended. They held with vigor that to survive the age of 
competition Muslims had reserved an equal right of development as Hindus had enjoyed in the fields of science and technology development and their representation in governmental bodies (1946, p.12). On the other side, there was also an emerging realization among Indians that the wellbeing of the poor population of agricultural rural areas was required for the sake of achieving industrial development. It was because they had represented about $80 \%$ of the Indian population providing 'a formidable potential market for industrial goods' (Desai, 2005, p. 108). Such demands were showing, to some extent, a disapproval of the government's lopsided emphasis on agricultural education versus other curricular forms of scientific-technical significance that were neglected during the Second World War times. Certainly, the wartime situation might have caused a set back to the existing vocational forms of knowledge that existed in some parts of India under the pre-World War Wardha scheme of education.

Saying this, such tilted emphasis on agriculture had borne at least good results. For instance, in general, societal terms, the introduction of radical agrarian reforms had entailed revising land relations and state funding for enhanced production affecting farmers to adopt new ways of agriculture and hence promising an increase in their purchasing capacity for general goods and industrial products (Desai, 2005, p. 108). In more specific terms, the Education Department of Punjab, for instance, had felt glad about the educational output as by 1946 two agriculture centers at Ludhiana and Jullundur were established and the subject of agriculture was also taught in 62 high schools and 340 middle schools (Government of Punjab, 1947, p.10). That trend had ensured the continuity of curriculum favoring agricultural education in secondary schools which were being observed with great zeal since the 1920s. Such efforts had borne good results for the farmers of rural Punjab whose children had learned new ways of farming, tilling their lands, and of making their lands more productive. Saying this, while the focus on agricultural education was being made as a consequence of British claims for adopting a diversified secondary curriculum during the early $20^{\text {th }}$ century, such emphasis was certainly directed towards the government's policy of 'Grow more Food' that had taken its practical shapes since 1941 onwards (Government of Punjab, 1947, pp.10-11). And the province of Punjab had shown incomparable efforts for achieving the goals of food sufficiency. In addition to the use of high school agricultural farms and plots, 'every inch of land on the school premises' were 'satisfactory irrigation arrangements existed was ploughed up and some food or fodder crop was sown' (Government of Punjab, 1947, p.17). The call for growing more trees had also shown great results as, by 1946, approximately 18,950 trees were being planted in the Eastern Circle of Punjab (Government of Punjab, 1947, p.17).

While during the peak years of the Second World War, the British Government had paid an added attention towards agro-based educational reforms in Punjab, with the war approaching towards its end they had accepted the significance of developing technical education along scientific lines for bringing the Indian population out of their miseries. The issue was brought up in 1946, when the leading scientists of the Empire presented papers dealing with 15 major topics of science when they assembled in the Empire Scientific Conference that was held in London, Cambridge, and Oxford. Comprising of 114 delegates from different British Commonwealth states, the Conference had received 38 members from the United Kingdom, and 14 delegates representing British India to share their views about such acclaimed post-World War issues (Miles, 1949, p. 405). Conference deliberations were held about several issues of common concern, including areas highlighting issues about agricultural and medical sciences in the Empire, the nature of scientific issues concerning nutrition of the natives of the Colonies, and the assemblage and exchange of scientific records and experimental material in the field of agriculture, etc. (Pendleton, 1950, p. 125). Perhaps, the conference had served as a milestone in the history of post-Second World War efforts for a better future through the advancement of scientific knowledge through collaborative ventures among the scientists of member states. No doubt, working together for the cause of scientific research in common areas of development was commendable. For Indians, working towards such an arduous task had implied a lot more to do in the post-World War context.

\section{Conclusion}

The onset of the Second World War had brought a shift in the secondary curriculum policy and its implementation in colonial Punjab. For their own sake, what stayed in common between the local needs of Punjab and the requirements of war was the focus on agricultural education in rural areas. In colonial Punjab, steps were being taken for the sake of developing the agricultural economy; and 
concerning fulfilling the needs of war times, active measures were being taken to increase food production. Similarly, the government policy discussions and local leadership demands for the diversification of Secondary Curriculum also went side by side with the ongoing war-centric secondary curriculum developments. The Second World War ended but left secondary education as a continuously evolving agenda as ever.

\section{References}

Biswas, A. \& Agrawal, S. P. (1994). Development of Education in India: A historical survey of educational documents before and after independence. Concept Publishing Company.

Collingham, L. (2012). The Taste of War: World War Two and the Battle for Food. Penguin.

Desai, A. R. (2005). Social Background of Indian Nationalism. Taj Press.

Ghosh, S. C. (1995). The History of Education in Modern India 1757-1986. Sangam Books Ltd.

Government of Punjab, Ministry of Education. (1921). Report on the Progress of Education in The Punjab for the Year 1919-1920. Lahore: The Superintendent Government Printing Punjab.

Government of Punjab, Ministry of Education. (1925). Report on the Progress of Education in the Punjab for the Year 1923-1924. Lahore: The Superintendent Government Printing Punjab.

Government of Punjab, Ministry of Education. (1929). Report on the Progress of Education in the Punjab for the Year 1927-1928. Lahore: The Superintendent Government Printing Punjab.

Government of Punjab, Ministry of Education. (1930). Report on the Progress of Education in the Punjab for the Year 1928-1929. Lahore: The Superintendent Government Printing Punjab.

Government of Punjab, Ministry of Education. (1943). Report on the Progress of Education in Punjab for the Year 1941-42. Lahore: The Superintendent Government Printing West Punjab.

Government of Punjab, Ministry of Education. (1944). Report on the Progress of Education in Punjab for the Year 1942-43. Lahore: The Superintendent Government Printing West Punjab.

Government of Punjab, Ministry of Education. (1947). Report on the Progress of Education in the Punjab for the Year 1945-1946. Lahore: The Superintendent Government Printing West Punjab, 1947.

Jackson, A. (2011). The Empire/Commonwealth and the Second World War. The Commonwealth Journal of International Affairs, 100, 65-78.

Jackson, A. (2006). The British Empire and the Second World War, MPG.

Jung, S. Y. (1946). Report on the All India Muslim Educational Conference Aligarh (AIMECA), 54th session held at Agra, dated 27-30 December, 1945. Muslim University Press. Translated from Urdu to English.

Kochhar, S. K. (2006). Pivotal issues in Indian Education. Sterling Publishers.

Krishnaswami, N. \& Krishnaswami, L. The Story of English in India. Foundation Books.

Lowe, R. (2012). Education and the Second World War: Studies in Schooling and Social Change. Routledge.

Miles, W. R. (1949). Review of the Royal Society Empire Scientific Conference, June-July 1946. Science, New Series, I \& II, 109405-406.

Mitra, R. S. M. \& Zachariah, K. Government of Bengal, Ministry of Education. (1933). Eighth Quinquennial Review on the Progress of Education in Bengal for the Years 1927-1932. Calcutta: Bengal Secretariat Book Depot.

Mohan, K. (2018) Punjab Agricultural College and Research Institute, Lyallpur (1906-1947): Generating Knowledge for Colonial Enrichment. Indian Journal of History of Science, 53(2), 205-223.

Nayar, D. P. (1989). Towards a National System of Education. Mittal Publications.

Pendleton, R. L. (1950). Review of the Royal Society Empire Scientific Conference, June-July 1946. The Quarterly Review of Biology, 25:1, 125.

Talbot, I. A. (1984). The Second World War and Local Indian Politics: 1939-1947. The International History Review, 6(4), 592-610.

Tomlinson, F. R. (1924). Impressions of the Imperial Education Conference 1923. Calcutta: Superintendent Government Printing India.

Webster, J. R. (1976). Curriculum Change and Crisis. British Journal of Educational Studies, 24, 203218. 